\title{
大規模多人数同時参加型オンライン ロールプレイングゲームのエスノグラフィ
}

一仮想世界において創発的サードプレイスをいかに生み育てるか

\section{高田佳輔*}

\begin{abstract}
先行研究では, 大規模多人数同時参加型オンラインロールプレイングゲーム の中に存在する仮想世界は, 自宅や職場から隔離された心地の良い第 3 の居場 所である「サードプレイス」としての機能を有するとされる。しかし，仮想世 界におけるプレイヤーの本来の目的は「ゲームコンテンツ」を楽しむことにあ り，どのような経緯で他者との世間話といった「交流」を目的に仮想世界に訪 問するようになるかが明らかでない. 本稿は, 同一集団に属するプレイヤーら の語りや「ゲームコンテンツ」と「交流」の各プレイ時間の推移から, 仮想世 界はゲームコンテンツへの没入期および欠そ期を繰り返すことで, 次第にゲー ムコンテンツを楽しむ場から交流を楽しむ場へと主役割が遷移する『創発的サ ードプレイス』であることを示した．また，創発的サードプレイスの成立には， サードプレイスの基盤を成す「交流」と, 各成員の能動的な参加が肝要な「集 団活動」との互恵関係が重要となることを示した.ゲームコンテンツ活動は, 集団を構成する成員が垂直的関係の中で共通目標の達成を目指すことで集団帰 属意識を向上させ，交流活動の基盤となるコミュニティの成員間のつながりを 維持・強化させていた. さらに, ゲームコンテンツ活動中の成員間の垂直的関 係性と, 交流活動における水平的関係性とが互いに侵食しないように作用させ る関係規範の存在が, 創発的サードプレイスの成立・維持に大きな影響を及ほ していた.

キーワード：創発的サードプレイス，オンラインコミュニティ, MMORPG
\end{abstract}

\section{1 問題の所在}

近年, オンラインゲーム市場は拡大の一途を辿っている. 国内のオンラインゲー ム市場規模は, 2013 年が 8,423 億円であり, 2014 年には 9,308 億円に達している (日本オンラインゲーム協会 2015). オンラインゲームとは, インターネットを経 由して，複数の人が同時に同じゲームの進行を共有できるゲームであり，そのジャ ンルは多岐にわたる（メディアクリエイト 2011）。その中でも, 大きな人気を維持

* 中京大学文化科学研究所 takadaruman@gmail.com 
し続けているのが, Massively Multiplayer Online Role-Playing Game（以下， MMORPG）である.

端的にいえば, MMORPGは, 自身が作成・命名したアバター1)を介在して, 仮 想世界の中で他のプレイヤーとの社会的ネットワークを築きながら冒険を行う協力 型ゲームである，プレイヤーは，仮想世界の中で現実とは異なる人格としてふるま うことが可能であり, 実際の性別, 年齢や職業にとらわれることなく, チャットを 用いたコミュニケーションや冒険を行うことができる．仮想世界内での各プレイヤ 一の役割は相互補完的であり，互いに助け合いながら冒険を行うことが重要となる. 同時に，他のプレイヤーは，競争相手でもあり，プレイヤーは，他のプレイヤーよ りも早く取得難易度の高いアイテムを獲得することが，1つのモチベーションとな っている. 以上のように, MMORPGの主な目的は他者と協力しながら冒険を完遂 し自らのアバターを強化するというロールプレイングゲーム部分にあるが, MMORPG をプレイしている最中は常に冒険を続けているわけではなく, 冒険の合 間に気心の知れた仲間との歓談がしばしば行われる，近年では，MMORPGのゲー ムとしての側面に加えて, 仮想世界内のコミュニティやその中でのコミュニケーシ ヨンといった対人関係ツールとしての側面に焦点が当てられ，余暇時間を過ごす際 の 1 つの「居場所」としての価值が注目されている（野島 2008）.

居場所は，その場所に参加する人員の特性によってその役割が大きく異なる。た とえば，荻野達史（2006）や川北稔（2014）は，不登校やひきこもりの青少年によ って構成される居場所を対象に，承認の決定的に欠如した外的空間から逃れる場と して，ユースワークや就労支援の側面から，アイデンティティの確立を支援するこ とによる自己信頼・自己価值感情の回復と志向性の探索に関する方法や，対象者の 社会参加のための空間の再獲得過程などに焦点を当てた検討を行っている．つまり， 自宅や職場（学校）における自己像の修正および獲得が主眼であるといえる．他方， R. Oldenburg（1989）や磯村英一（1959, 1968）は, 自宅と職場（学校）という確 固たる居場所はあるが，その 2 箇所を往復するのみの作業的な日々を過ごす個人を 対象に，自宅や職場の社会的ネットワークから解放される場として，身分，地位や 役割などからの一時的な解放から生ずる精神的な安寧や新たな関係資本の獲得を主 な目的とした検討を行っている。本稿は, Oldenburg がサードプレイスと呼称す る，自宅や職場において他者からの承認を経て確立した自己像を有する個人が，社 会的望ましさから解放され精神的安寧や新たな関係資本を獲得するための居場所と して，MMORPGの仮想世界の利用可能性を検証することを目的とする.

サードプレイスは，ファーストプレイス（自宅）やセカンドプレイス（職場）の どちらの社会的ネットワークとも重複せず, 人々が社会的望ましさを要求される日 常の環境から逃れ, 新たに構築される関係から資本を獲得できる場所を指す. Oldenburgは, サードプレイスの 7 つの特徵として, (1) 中立領域, (2) 平等主義,

（3）会話が主たる活動，（4）利用しやすさと便宜，（5）常連の存在，（6）目立たな い存在，（7）雲囲気に遊び心がある，といったもう1つのわが家のような場所であ 
るとしている.

以上のサードプレイスの特徵から導出されるのは, MMORPG における仮想世界 の環境との類似性である．たとえば，C.A. Steinkuehler \& D. Williams（2006）は， 海外で流行する MMORPGの仮想世界環境とサードプレイスの特徴との関係につ いて質的な側面から検討を行っている．彼らは，いくつかの MMORPGを対象に, プレイヤーの発言やフィールドノートのデータを用いて, サードプレイスの諸定義 と仮想世界の特徵とを個々に照合し, 仮想世界のサードプレイスとしての利用可能 性を示している. 次いで, N. Ducheneaut et al.（2006）は，質と量の両側面から, 仮想世界の環境とサードプレイスの定義との照合を行い, 仮想世界の環境がサード プレイスの定義の一部を満たしていることを明らかにしている．以上のように, MMORPG の仮想世界環境は, Oldenburg の提唱するサードプレイスの諸特徴と大 筋で一致し，プレイヤーが仮想世界に対して「ゲームコンテンッ」によって自らの アバターを強化することを楽しむという本来の目的に加え, 他のプレイヤーとの愉 快かつ有益な「交流」という目的を見出していることが示されている. 先行研究で は, 従来のサードプレイス論における要点である「地域性」がないことを認めなが らも, MMORPG にはサードプレイスの効果の 1 つとして期待される人間関係の中 から生まれる資本の獲得はなされていることを明らかにすることで, サードプレイ ス概念の拡張が目指されている. 本稿では, 先行研究に依拠し, 従来のサードプレ イス論を拡張する形で, 新たなサードプレイスの形態について論じる.

しかしながら, 先行研究においていまだ明らかでないのは, 次の 2 点である.

第 1 に, プレイヤーにとって, 本来「ゲームコンテンッ」が主目的である MMORPGの仮想世界が, 「交流」を楽しむサードプレイスとしての機能を獲得し た経緯が明らかにされていない. 本問題は, 現実世界におけるサードプレイスを対 象とする研究においても同様に存在する. たとえば, 久繁哲之介（2007）は, サー ドプレイスとして安定的に機能している施設としてスポーツクラブを挙げ, 主目的 が「交流」であり，従目的が「競技」であることを示している．しかしながらここ でも同様に，利用者がスポーツクラブに訪問する当初の主目的は「競技」であり， 休憩スペースでの「交流」ではないと考えられるが，その主目的が移行するに至っ た経緯が明らかにされていない. 以上の, 目的の遷移過程が明らかとなれば, 田中 康裕ほか (2007) で示されるコミュニティ・カフェのような利用者間の交流が主目 的であることを意図して一から構築されるサードプレイスとは異なる，いわば「創 発的サードプレイス」の成立条件の一端を明らかにできよう。

第 2 に, 仮想世界においてプレイヤーらが主体となって発足する, オンラインゲ 一ム一般でギルドと呼称される, 同好会の実態が明らかにされていない. 同好会に 所属することによって,「ゲームコンテンツ」および「交流」といった活動が促進 されることから, 仮想世界がサードプレイスとして機能するにあたり, 同好会の存 在は重要な要因になっている（Steinkuehler \& Williams 2006). しかしながら, 彼 らは,「ゲームコンテンツ」場面では, 成員間にリーダーとフォロワーという垂直 
的関係が存在することを示している.つまり, 先行研究では, 同好会は「ゲームコ ンテンッ」を効率的に楽しむためにプレイヤーに垂直的関係を生じさせる一方で, サードプレイスの要件として重要な, 成員間の水平的な関係性を有するという構造 的矛盾が生じている，本稿では，仮想世界における同好会の形成・発展過程，およ び，構造と実態を明らかにした上で，同好会が仮想世界のサードプレイスとしての 機能に及ぼす影響を検討する。

\section{2 調查方法}

\section{1 対象とする MMORPG の概要}

本稿は, 現在, 日本で流行している MMORPGの 1 つである Final Fantasy XIV （以下，FFXIV）を調查の場として選定した，FFXIVの利用料金は，月額 1,000 円から 1,500 円程度となっている.

\section{2 対象とする集団および対象者}

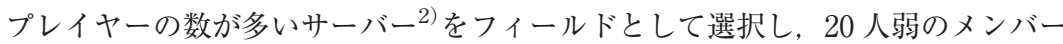
を有する同好会 (以降, フリーカンパニー) ${ }^{3}$ に所属するプレイヤーを調查対象者 とした，フリーカンパニーとは，FFXIV の仮想世界に存在するプレイヤー主体で 形成する集団を指す．フリーカンパニーの主な役割は，一緒に特定のコンテンツに 挑戦する人員の確保，世間話の相手の確保，情報の共有などがある.

\section{3 データおよび調査手続き}

調査手法に関しては, 先行研究に依拠した参与観察およびインタビュー調查を行 った，その際，ゲーム内活動に意欲的かつ活動時間帯が近しい 5 人のプレイヤー を主な調查対象とした．本調査は，筆者が調查者としてゲームに参加していること をあらかじめ対象者に伝えた上で, 冒険者の 1 人として行動しながら, 観察を行い, フィールドノートを作成した．フィールドノートは，仮想世界内で自然に生じた会 話をそのまま保存したテキストと，場の䨌囲気やキャラクターの動きなど会話以外 の事柄をメモ書きしたテキストの 2 つであった。 また，対象者が仮想世界で活動す る中で生じた感情や認識の変化等について, 半構造化による聞き取りを仮想世界内 で文字チャットを用いて都度行い，インタビューデータとしてまとめた.

加えて, 各対象者のゲームプレイ時間データを観察可能な限り収集した。詳細に は，フリーカンパニーの成員とアバターの強化という共通目的を目指す「ゲームコ ンテンツ」活動，および，同成員と単なる世間話を行う「交流」活動時間をそれぞ れ区別して計測した．筆者が訪問する以前から対象者が仮想世界にいた調査日につ いては, 該当対象者に訪問時刻と打㧍よその活動内容を尋ね, 補完を行った。 なお, 補完日については全体の10\%以下に収まっている.

フィールドワーク期間は, 2013 年 8 月 27 日から 2014 年 8 月 30 日であり, メン 


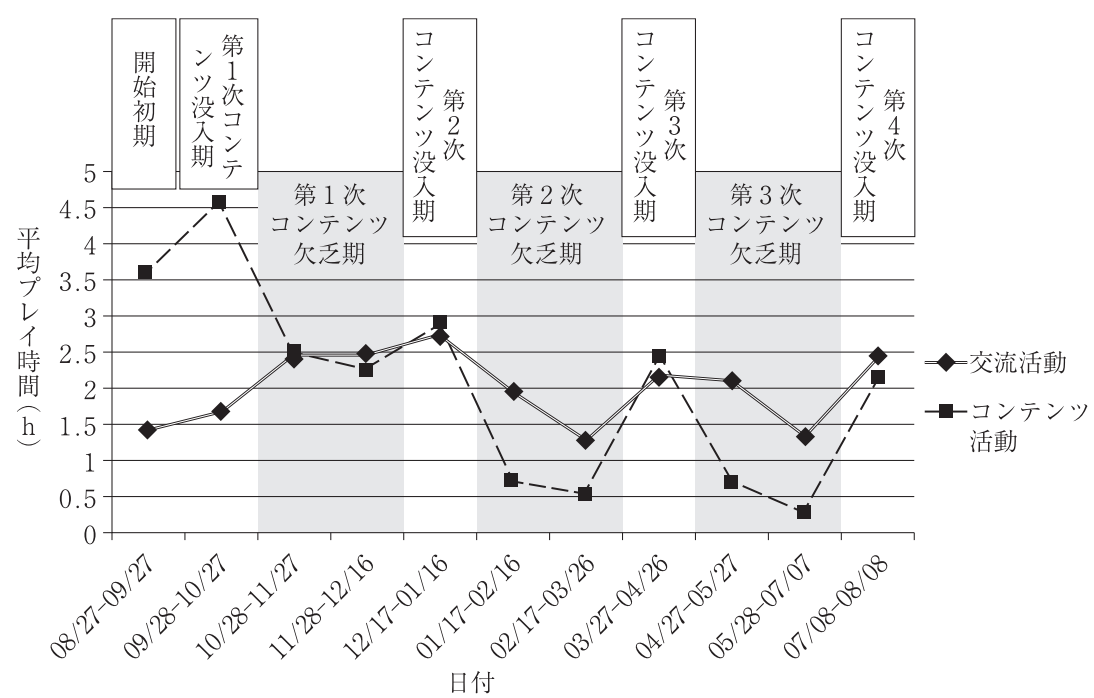

図 1 期間ごとの対象者の平均プレイ時間数

テナンスでサーバーが閉鎖される日を除き，毎月 25 日以上の頻度で行った．時間 帯は主に, 午後 8 時頃から午前 2 時頃までであった.

\section{3 仮想世界における活動内容の変遷}

本稿で対象とする FFXIV は, プレイヤーが仮想世界の中で冒険を楽しむ MMORPG としてサービスが提供されている. 本節では, プレイヤーが仮想世界に はじめて参加した時点から，「一流の冒険者」5)として成長するまでの経過を観察す ることで，プレイヤーの仮想世界における活動内容の推移を概観する．また，その 際に, 各対象者のフリーカンパニーでの活動の中で, パーティを構成し共通課題の 達成を目指す「ゲームコンテンツ」への取り組みに充てられた活動時間と, 世間話 による「交流」に割かれた時間を併せて概観することで, 量的側面においても上記 の変遷の確認を行う。図 1 は, 対象者 5 名の「ゲームコンテンツ」および「交流」 に費やした時間数の各平均值の変動に加え, 対象者をとりまく仮想世界のおおよそ の環境状態を時期ごとに示している ${ }^{6)}$ ，なお，第 2 ，第 3 および第 4 次コンテンツ 没入期には, ゲームのバージョンアップが行われ, 新たなゲームコンテンツが追加 されたことから，一時的にゲームコンテンツ活動時間が増加している.

以降では, 図 1 に示される,「開始初期」, 第 1 から第 4 次「コンテンツ没入期」, および, 第 1 から第 3 次「コンテンツ欠そ期」という仮想世界の環境状態を表す期 間の区別ごとに，プレイヤーの活動の内実を明らかにしながら，時期ごとに仮想世 界の役割の推移を概観する。 


\section{1 開始 初期}

本稿において, 開始初期は, プレイヤーがゲームにはじめて参加してから, 高難 度のコンテンツへと参加が可能な，レベル7)が上限に達した状態に到るまでを指す． 本期間において, プレイヤーの活動形態は, 単独活動における戦闘経験の蓄積を経 て，プレイヤー同士でパーティを構築して行う集団活動へと移行していく.

開始初期は「とりあえず攻撃の仕方とか，キャラ $\left[\right.$ アバター ${ }^{8)}$ の動かし方とか 覚える. [中略］ゲームのことばっか考えてる時期だな．とにかく早くレベル上げ たくてうずうずしてた」闭時期であり，プレイヤーが仮想世界に対してゲームコン テンツ部分の楽しみを強く希求する時期である.

以降では，ゲーム「開始初期」に抏いて，プレイヤーが単独执よび集団の活動経 験を経て, 仮想世界で「一流の冒険者」となり,「コンテンツ没入期」に向けて今 後の活動基盤となるフリーカンパニーを形成する過程を概観する.

\subsection{1 単独活動期}

ゲーム参加からしばらくは, 単独でさまざまな活動を行うことで, 自身のレベル を一定量上昇させることが目的となる，たとえば，特定のモンスターを 10 匹倒せ， というものや，特定の対象人物に微笑もう，といった内容である。これらの活動を 通じて, プレイヤーは, 自身の職業役割 ${ }^{10)}$ を正しく認識し, 集団活動に向けての 形式知を獲得する.

\subsection{2 集団活動および集団形成期}

単独活動期を経て, 集団活動に最低限必要な形式知を獲得したプレイヤーは, プ レイヤー同士で集団を構成して, 迷宮を攻略する集団活動等に参加するようになる. 集団活動は, 単独でレベルを上昇させる活動（以降, レベル上げ）と比較して効率 に優れるため, 以降のレベル上げの手段として選択されることが多くなる.

レベル上げを目的とした集団活動を通じて，プレイヤーは，他のプレイヤーとの 交流を行う。その結果, プレイヤーは, フレンド11)を作ったり, フリーカンパニ 一を結成，もしくは，既存のフリーカンパニーから勧誘されたりする.

レベル上げの時にフレ [ンド] ができることが多かったな.FATE［集団活 動の一種］で即席パーティ作って 2 時間くらいやってた時は, ずっと [パーテ イのメンバーと］喋りながらやってたから，フレンドがたくさんできた，今の フリカン [フリーカンパニー］にいるプレイヤーDもそこで会って, 俺が勧 誘した.（データ 1: プレイヤーB）

開始初期には，黑々とレベル上げを行う集団活動に加え，「喋りながらやってた」 としても支障がないような集団活動が存在し, レベルが上限に達するまで繰り返し 行われる，それにより，プレイヤーは交流の機会を繰り返し得られる．このように， ゲーム開始初期の仮想世界では, フレンドの獲得やフリーカンパニーへの所属が自 然に行われるようなゲーム設計がなされている. 


\section{2 コンテンツ没入期——固定パーティによるコンテンツ活動}

開始初期における単独・集団活動扔よび集団形成を経て, レベルが上限に達した プレイヤーは, 当該時点で最も優れた装備品やアイテムの獲得を目指して複数の高 難度コンテンツに挑戦するようになる. 高難度コンテンツとは, 複数人のプレイヤ 一が大縄跳びの最中に時限爆弾を解除するような緻密かつ困難な作業である（高田 2016). 調查時点に扔ける高難度コンテンツは, 8 人のプレイヤーでパーティを構 成し, 90 分の時間制限の中で特定のモンスターを撃破し, 報酬の装備品・アイテ ムを獲得することが目的であった。

高難度コンテンッへ挑戦する集団は, 高田（2016）が示すように, 緻密かつ高難 度の協調的作業が求められる活動ゆえに, 成員は可能な限り固定的であることが望 ましいとされる. 成員が固定的な集団でコンテンツに挑むことで, 集団単位での経 験の蓄積や，成員間のつながりをいっそう堅強なものとし，コンテンツのクリア可 能性を高めることができる，なお，本稿では，フリーカンパニーの成員によって形 成される比較的成員が固定的なパーティ（固定パーティ）を対象とし, 以下の検討 を行う。

以降は, 固定パーティによる高難度コンテンツ経験が, フリーカンパニーにおけ る成員間のつながりに及ぼす影響を概観する.

本項では, 高難度コンテンツ活動について, 古籏安好（1965）による協同の集団 効果の観点から, 集団の凝集性・生産性・参加性の相互関係に着目しながら, 固定 パーティに扔ける集団活動の内実を明らかにする.

バハ［高難度コンテンツ］は初［めて］クリア［した時］の達成感が半端な い. 大体初クリア [の時] はみんな $\mathrm{DPS}^{12)}$ とかギリギリの状態で, フォロー し合いながらのクリア [の状況 $]$ が多いから，みんな「う扔扔扔」って［盛 り上がる．そのあと， [報酬の］宝箱開ける時も盛り上がるし，バハから帰っ てきた後も，フリカン［フリーカンパニー］のチャットで盛り上がる.「あの 時の対応，神だった」とか裹め合ったり，「俺よりDPS 低い戦犯扔る？」とか [染談で］弄ったり，クリアするたびに戦友感が上がる.（データ 2: プレイヤ $-\mathrm{C})$

「ギリギリの状態で, フォローし合いながらのクリアが多い」高難度コンテンツは, パーティの中で最も作業に対する出来が悪い成員のパフォーマンスを，いかにフォ ローできるかでクリアの可否が分かれる.クリアができれば報酬が獲得可能であり， できなければ報酬はまったく得られないことから，集団の生産性を最大にするには， クリアは必要条件となる. そのため, 出来の良い成員は, 出来の悪い成員を可能な 限りフォローしなければならない，ただし，以上の出来の良し悪しによる関倸性は， 挑戦するコンテンツの内容によって, 成員間でその立場が逆転する場合が多々存在 する. 高難度コンテンツは, 全成員が常に高いパフォーマンスを維持し続けなけれ 
ばクリアが困難な難易度となっていることから，誰しもが出来の悪い成員，いわゆ る「戦犯」になる可能性がある.

［高難度コンテンツに］はじめて行く時は，大体 2 分保たずに全滅する．［中 略］一から試行錯誤するしかない. 全滅して, 意見出し合って, 対処法決めて, 実行して，また全滅する。最初とか常時綱渡り状態だから，みんなが精神的に 参ってきたら終わり．1チャレンジでクリアなんて絶対無理. 最初なんか「な にこの無理ゲー」って思いながらやってるし. まあその無理を可能にするのが 気持ちいいんだけどね.（データ 3: プレイヤーA）

高難度コンテンツでは，「最初に行く時は，大体 2 分保たずに全滅する」ような 作業の困難性ゆえに，作業を完遂するために「試行錯誤するしかない，全滅して， 意見出し合って, 対処法決めて, 実行して, また全滅する」といった Plan-DoCheck-Act (PDCA) サイクルの循環が行われる. 加えて, 高難度コンテンツは, 1 トライが長くとも 10 分程度であり, 成功か失敗かがモンスターを撃破できたか 否かという点で明確であることから, PDCA サイクルは非常に早く循環する. 失 敗したとしても成員が失うものは作業に要した時間程度であり, 意見の提案から実 施および結果の確認までのコストが非常に少ない点は，成員の参加性を向上させる 一助となっている，以上のように，PDCA サイクルを短い間隔で循環させること で，集団の成員に能動的かつ積極的な参加を促し，「無理を可能にする」といった 勝利が生産される.

以上のプロセスを繰り返す中で，固定パーティにおける集団の凝集性が向上する こととなる.

［高難度コンテンツは］大体自分の役割が決まってるじゃん．俺は, 2 層 ［高難度コンテンツの一種］だと巨人の管理やってるけど，俺にしかできない ことだから緊張する。たまにミスって全滅させることあるけど，みんな許して くれるから優しいわー。野良 [成員が流動的なパーティ］だと 1 回でもミスる とすげー空気悪くなって，すぐギブ [アップ投票 ${ }^{13)}$ するからきついな. こっ ち［固定パーティ］だと［作業の］難しさをわかってくれて，やばい時はフォ ローしてくれるから［作業に対する］やる気が違うな.（データ 4: プレイヤ $-\mathrm{E})$

高難度コンテンッでは，困難かつストレスフルな作業が，集団に対して「ギブアッ プ」を行わせようとするが，「難しさをわかってくれて，やばい時はフォローして くれる」パーティの成員らによる抵抗が集団の崩壊を防ぎ，作業を継続させている. この集団の抵抗力の背景には，プレイヤーA が「これ［巨人の管理］はプレイヤ ーEにしかできないから, ミスあっても無駄に責めないようにしょう」という事 
前の提案を行い, 皆が賛成するというプロセスがあった. このような成員間の配慮 が，プレイヤー E を固定パーティへと留まらせる一助となっていた.

高難度コンテンツは， 8 人という人数制限の中で各成員が「ギリギリの状態」で 作業を進行させるという点で, 人海戦術ではなく個々人のパフォーマンスを最大に することが，課題達成につながる仕組みになっている，したがって，固定パーティ で高難度コンテンツに挑戦した場合には，各成員に自分にしかできない役割がある という点で集団への参加性が向上し, それがコンテンツのクリアという集団の生産 性の向上につながっている，さらに，以上の固定パーティによる高難度コンテンツ 活動経験の反復が，のちの集団の凝集性を向上させる一助となっている.

\section{3 コンテンツ欠乏期}

大半の MMORPG はエンディングが存在しないことが特徵であるが, それは FFXIVも同様である。それゆえに, 既存のゲームコンテンツにおける目標をすべ て達成してしまい, 仮想世界で特段行う活動がない期間が生じることとなる.

バハ [高難度コンテンツ] 全部終わったら, やることがないよなー。週 1 で バハ行って 1 日で終わるから，他ですることは神話稼ぎ［コンテンツの一種］ とか? それも週制限あるからなー。 あとはほかのメンツの手伝いとか？こう考 えるとバハ早くクリアしすぎるのも問題だな.ログイン［仮想世界に訪問］し て，フリカン［フリーカンパニー］でだべるだけってのが多くなる。（データ 5: プレイヤーD)

FFXIVでは「週制限」というゲーム上の設計によって, 1 週間に 1 度しか課題を 達成できないコンテンツが存在する，週制限の対象の大半は, 高難度コンテンツで あり, 週をまたぐと解除される。この設計によって, プレイヤー間にゲーム進行率 の点で大きな差異が生じないようにされている，それゆえに，一部プレイヤーにと っては，経験の蓄積から，週始め時点で大半の高難度コンテンツをクリアできてし まい,「やることがない」期間が多く存在することとなる。しかしながら, 図 1 に 示されるように，プレイヤーはやることがないからといって，仮想世界にまったく 訪問しなくなるわけではなく，特に目的がない中でも仮想世界自体には「ログイン して,フリカンでだべる」ことは継続される.

\section{4 コンテンツを楽しむ場から交流を楽しむ場への移行 創発的サードプレイスの成立——}

では，プレイヤーはコンテンツ欠そ期において，何を目的として仮想世界に訪問 するのか. 図 1 のプレイ時間に着目すると, 各コンテンツ没入期を超え, 各コンテ ンツ欠そ期に入ると, フリーカンパニーでの「交流」に費やす時間と「ゲームコン 
テンツ」活動に費やす時間とが逆転していくことがわかる．つまり，プレイヤーの 仮想世界における主目的が，「ゲームコンテンツ」から，気の合う仲間との「交流」 へと移行していることが確認される.

\section{1 仮想世界のサードプレイスとしての機能}

次の代表的な語りから示されるのは, 仮想世界にサードプレイスとしての役割が 創発されること，および，その際にフリーカンパニーが果たす役割の重要性である.

ログイン [仮想世界に訪問] するのはもう生活の一部だなあ. 残業があって もとりあえず少しでもログインだけする，息抜き。イン［訪問］したらこん中 [フリーカンパニー］の誰かはいるし，いなくてもそのうち誰かインしてくる. [中略］会社の飲み会も別に良いんだけど，結局上司には気を使わないといけ ないし，部下もいるから面倒も見ないといけない。ここだと何のしがらみもな いからいいよ，気の知れた仲間って感じ，糞みたいな話してるだけだけど笑え る。趣味合うから．大体話題にも入っていける，雑談がメインで，他 [ゲーム コンテンツ］がオマケみたいになる日が多いな，まあ，それはお前もだろ. (データ 6: プレイヤーB)

仮想世界は, Oldenburg（1989）が示すサードプレイスの 7 特徵である，「何の しがらみもない」（1）中立領域であることや, MMORPG 特有のプレイヤー間の （2）平等性,「杂倠談がメインで, 他 [ゲームコンテンツ] がオマケみたいになる日 が多い」といった（3）会話が主な活動となっていること，「残業があってもとりあ えず少しでもログインだけする」ことができる（4）利用しやすさと便宜性を有し, 「インしたらこん中の誰かはいるし，いなくてもそのうち誰かインしてくる」よう な（5）常連の存在を期待でき, 上司にも部下にもみつからない（6）目立たない場 所にあり，「糞みたいな話してるだけだけど笑える」（7）遊び心のある雲囲気に満 たされる，もう 1 つのわが家のような居場所となっている. FFXIVの仮想世界に おける特徴は, 先行研究においてサードプレイスの機能が既に確認されている海外 の MMORPGの環境と大部分で一致していた.

\section{2 仮想世界のサードプレイスヘの移行経緯}

また，図 1 において確認すべき点は，プレイヤーのコンテンツ消化率が高まるほ ど，ゲームコンテンツに費やす時間は減少するということである. 開始初期から第 1 次コンテンツ没入期については, プレイヤーD D 「最初はとにかくコンテンツ が楽しかったよ．最初はとりあえずクリアできれば楽しかった」と述べており，ゲ ームコンテンツへの没入度の高さが窅える. 実際に, 同時期においては, プレイ時 間の中でコンテンツに費やす時間の割合が高い.しかしながら，コンテンツ欠そ期 になると，プレイヤーは大半のコンテンツを既にクリアした状態になり，ゲームコ 
ンテンツへのモチベーションは以前と比較して著しく低下する．プレイヤーC コンテンツ欠そ期の状況について，「単純にやることがない」と表現しており，ゲ ームコンテンツ自体にはあまり魅力を感じていない時期であることが窅える.

しかしながら，コンテンツ欠そ期には，仮想世界に上述の高難度コンテンツなど の多くの苦難を乗り越えてきた仲間が所属するフリーカンパニーの存在があること から，プレイヤーはフリーカンパニーの成員との交流を主目的に仮想世界に訪れる ようになる（データ 7). その時期に, プレイヤーは仮想世界に訪問する目的が変 化したことを認識し，仮想世界にサードプレイスとしての役割が創発される.

邂逅編［第 1 次コンテンツ没入期］あたりまではコンテンツをクリアするの が楽しかった。一人でも，みんなでもね。でも極夕イタンあたり [第 2 次コン テンツ没入期］では，仲間とコンテンツをクリアすることが楽しくなった．多 分, 一緒にいる時間が長いせいだろうけど. せっかくだから一緒にクリアした いし，すれすれの勝利が気持ち良いし，それをみんなで一緒にできたらいいじ やんみたいに感じるようになった。 クリアしたあとに, それをネタに盛り上が れるしね. (データ 7: プレイヤーE)

「邂哌編あたりまではコンテンツをクリアするのが楽しかった，一人でも，みんな でも」との発言からは, 開始初期および第 1 次コンテンツ没入期では, まだゲーム コンテンツ自体に没頭している様子が窅える。しかしながら，「極タイタンあたり では，仲間とコンテンツをクリアすることが楽しくなった，多分，一緒にいる時間 が長いせいだろうけど」というように，第 1 次コンテンツ欠乏期における仮想世界 に求める役割に対する認識の変化への気づきが, 第 2 次コンテンツ没入期には「み んなで一緒にできたらいいじゃんみたいに感じる」ようにさせるきっかけとなって いる.

極タイタン [第 2 次コンテンツ没入期 $]$ やり尽くしたあたりからこっち［仮 想世界］にくる目的が話をしにくる感じになってたかなー。なんか前はコンテ ンツの合間に「疲れたから話でもするか」って感じだったけど, 今 [第 3 次コ ンテンツ欠そ期では「話すことなくなったからなんかコンテンツでも行 く?」って感じ? コンテンツやる気力ない時とか, 完全に雑談目的のログイン だよね.（データ 8: プレイヤーD）

没入期と欠そ期を繰り返し経ることで，「目的が話をしにくる感じになってた」 と示されるような, 仮想世界に求める役割に対する認識の変化への気づきが深まる. 加えて, 没入期にゲームコンテンツを繰り返し行うことでフリーカンパニーへの帰 属感が向上し, 成員間の信頼関係が十分に構築されていることを認識することで, 交流場面において現実世界に波及する支援が得られる経路が形成される. 
どんどんフリカンがガキの頃の秘密基地みたいになっていくんだよな. 最初 はゲームやるぞって感じで来てたけど, 今［第3次コンテンッ欠そ期］じゃあ いつらに顔見せに行くかって．戦友的なノリ？背中を任せられるみたいな.

[中略］仕事の相談とかも気軽.「こいつになら相談してもいいかな」って．あ っち［現実世界］ではできない恋愛相談とか仕事の相談とか気づいたらするよ うになってた（データ 9: プレイヤーB）

データ 9 に扔ける「あっちではできない恋愛相談とか仕事の相談とか気づいたらす るようになってた」との語りには, フリーカンパニーという「背中を任せられる」 「戦友」が多数存在する人的ネットワークから生じる支援効果の現実世界への波及 可能性が示されている. この支援は, ソーシャルサポートと解釈が可能である. 中 でも，データ 9 のように自分の問題について他者に相談することができる情緒的サ ポートの獲得可能性については, プレイヤーCが「転職の相談とか, リアル [現 実世界]では誰かに聞かれたり，噂が広まったりがあるからできない。こっちだと 気軽にできる，信頼もできるし」と語って抢り, さらに他の対象者からも同様の語 りがみられた。 また実際に, プレイヤーBは, プレイヤーAに恋愛相談を繰り返 し行うことで, 友人関係であった個人と婚約に至ったことを報告している. 以上か らは，仮想世界の中でも現実世界に波及するような支援が獲得できていることが窅 える。

\section{5 フリーカンパニーが創発的サードプレイスの機能に及ぼす影響}

以上の結果を勘案すると，フリーカンパニーは，仮想世界において「ゲームコン テンツ」と「交流」の両目的を充足し, 状況に応じて集団形態を遷移させる, 二重 構造を成す集団であるといえる.

\section{1 ゲームコンテンツと交流との間の関係規範}

また特記すべきは, 仮想世界のフリーカンパニーは, リーダーとフォロワーとい った成員間の関倸性が垂直的な「ゲームコンテンツ」活動と関倸性が水平的な「交 流」活動との間で, 状況に応じて交互に集団形態を変容させる際に, その垂直およ び水平的関係性を成員が意図的に遷移させていないことである，成員間の関倸性の 遷移について, プレイヤーBは,「エンドコンテンツ［高難度コンテンツ］での) リ［上下関係］を，外 [普段の交流］に持ち出すのは夕ブー」と述べており，また 調查期間中に最もリーダーの役割を果たす機会が多かったプレイヤーAは，「バハ [高難度コンテンッ] では私はリーダーというか指揮をとること結構多いけど, 普 段はそんなの [上下関係］ないし，そんないつも偉そうな奴がいるなんて考えるだ けでも麥陶しいわ，むしろ普段は場を荒らすふざけたキャラでしょ，私．でもバハ ［高難度コンテンツ］にこんなの［ふざけた人］がいたらキレる」と述べている． 
以上のように，プレイヤーは，ゲームコンテンツ場面では統制された人間関係の方 が作業効率を高める一方で, 日常の交流場面では平等な人間関係の方が愉快な交流 が促進されることを認識している.

では,「ゲームコンテンツ」と「交流」との相互遷移間に存在する，「タブー」と 称される，両活動における成員間関係性を不可侵なものとする関係規範はどのよう に形成されたのであろうか. その一因には, 国内 MMORPG 文化の黎明期から観 察される，MMORPGのゲーム設計に起因する仮想世界の活動全般におけるプレイ ヤーの効率主義的な姿勢が挙げられる.

初期 [黎明期］の MMO は，とにかくレベル上げがダルかった. FFXI ${ }^{14)}$ は， とにかく何回もモンスターを倒してレベルを上げるしかなかった．最初はレベ ルが上がりやすいんだけど，それがどんどん上がりにくくなっていって，[中 略］それからは，みんな 1 時間でどれだけ稼げるか，時給 [時間効率］を考え て倒すモンスターを選ぶようになった，その後やった他の MMO でも, 効率 を第一に考えて活動することが常識になってた（データ 10：プレイヤーB）

データ 10 からは, 国内 MMORPG 文化黎明期より, 開始初期における, RPGの根 幹となるゲームシステムである「レベル上げ」が非常に時間の掛かる作業であった ことから, ゲームコンテンツ場面では目標達成に向けた作業の効率化を第 1 に考え て活動するという思考が多くの国内プレイヤー間で共有されてきたことが示され る ${ }^{15)}$ ，その背景には，アバターを強化するためにはレベルを上昇させることが必 要不可欠なことや，一定の数值までレベルが上昇しない限り物語が進行しないとい った、レベルを上げることを前提としたゲーム設計による影響が存在した.

さらに, 以上の効率主義的な姿勢は, ゲームコンテンツ場面だけでなく, 交流場 面においても開始初期に別途観察されるようになる。プレイヤーが考える交流場面 における効率化の指針は, ゲームコンテンツ場面とは内容が異なり，迷惑な個人と の交流は極力避けながら，愉快に交流が行えそうな個人を対象につながりを形成す ることにある ${ }^{16)}$ 。つまり, 交流場面における効率化は, 仮想世界の根幹的特徴で あるプレイヤー間の「平等」性を遵守することで，良好な関係性を速やかに構築・ 維持し，愉快な交流を継続的に行うことを目的としている.

普段 [交流場面］はその［ゲームコンテンツ場面の］反動で，まったりで行 こうっていう流れができてたかな.だから，普段まで偉そうに上から目線で指 図するやつは，割と空気読めない奴扱いだったね，そういうの見るとこっちま で恥ずかしくなる。［中略］．［仮想世界は］みんなスタート地点が一緒なわけ だから，基本みんな平等でいようって普通考えるよね．現実は出産ガチャ［遺 伝子的な差があるわけ］だから余計に。（データ 11：プレイヤーA） 
データ 11 からは，仮想世界は現実世界とは異なり生得的能力による格差がなく 「みんなスタート地点が一緒」という理由から，特段競争や課題の与えられない世 間話的な交流場面では極力「まったり」とした水平的関係性を重視することが，交 流を円滑化させるための効率的な方略であることをプレイヤーが認識していること が示される，実際に，交流場面においては，ゲームコンテンツ場面での垂直的関係 性にみられる指示が「偉そうに上から目線」とみなされ，恥と感じられる程に場に ふさわしくない態度とされた。

やがて「開始初期」から「コンテンツ没入期」以降へと移行することで，交流活 動を基に構築された集団である「固定パーティ」でゲームコンテンツ活動を行う機 会が増え，これまでそれぞれ異なる成員で主に行われてきた両活動が，同一成員で 交互に繰り返し行われるようになる，次の代表的な語りから窥えるのは，その際の 両活動における成員間関倸性の不可侵性である.

どっちも大事だからな．線引きだな．エンジョイ［まったり］勢とか言って エンド［ゲームコンテンツ］来られても迷惑だし，ガチのノリをその後［交流 活動にに持って来られてもな.（データ 12: プレイヤーE)

プレイヤーは，仮想世界における「どっちも大事」な活動であるゲームコンテンッ と交流活動との互いに異なる成員間関倸性の維持を行うために，「ガチ」と「まっ たり」という集団特徵の区別にもみられるように，相互に不可侵とする関係規範を 形成することで，状況によって垂直的関係性と水平的関倸性とを切り替える方略を 実行していた．以上の国内 MMORPG 文化の黎明期より形成された関係規範が， 本稿の対象とする FFXIV にも形成・適用され，交流場面に扔ける成員間の水平的 関係性を維持し，仮想世界にサードプレイスの機能を創発する一因となっていた.

\section{2 ゲームコンテンツ活動と交流活動との間の互恵性—集団の維持・強 化と動機付け}

他方で, 前述のゲームコンテンツ活動で向上した集団凝集性および参加性は, 交 流活動の基盤となる集団への帰属意識を向上させ，さらにゲームコンテンツ活動へ 参加する動機付けの役割を果たしている。

バ八［高難度コンテンツ］クリアした後はフリカン［フリーカンパニー］が 盛り上がるよな. みんなで試練を乗り越えた感が半端ない.やっぱ揃頼れる な，ってみんなでなる，なんかこうやって言葉にすると恥ずかしいけど．次も みんなとクリアしたいって思う。(データ 13: プレイヤーC)

ゲームコンテンツ活動後の交流場面では,「やっぱお前頼れるな」などの発言を通 じて成員間で互いの実績を賞賛し合う機会が設けられ，自身が集団内で重要な役割 
を積極的に果たしていることを他者評価によって確認し, 帰属意識が高まる。州属 意識の向上によって,「俺にしかできない」作業内容の遂行を求められるコンテン ツ活動に対して,「次もみんなでクリアしたい」というような参加への動機付けが 行われている.

以上から導出されるのは, 仮想世界がサードプレイスとして役割を担うためには フリーカンパニーにおける「交流」活動がもちろん重要となるが, 他方で「ゲーム コンテンツ」活動が，その交流の基盤となるフリーカンパニーの成員間のつながり を維持・強化していることである. 図 1 のコンテンツ活動および交流活動時間にお ける対象者の平均值の推移において, ゲームコンテンツの活動機会は, 開始初期に はフリーカンパニー形成の役割を果たし，また，コンテンツ欠そ期において衰退し たフリーカンパニーの立て直しの役割を果たしていると解釈できる．つまり，仮想 世界では, ゲームコンテンツと交流との活動バランスによって, サードプレイスの 基盤となるフリーカンパニーの活気および集団の維持が行われており，コンテンツ が欠そすることによってゲームコンテンツ活動が行われなければ，集団維持の機会 が不足し，サードプレイスとしての機能も徐々に衰退する。実際に，「コンテンツ 追加されると，フリカンのみんなでやるから一緒にいる時間が増える」ことや， 「終わったら気持ち悪く互いに㨐めあったり，[中略］おしゃべりタイムが始ま る」17) という語りから, コンテンツ追加による集団課題の提供が, フリーカンパニ 一内でコンテンツ活動と交流活動との循環を促し, 成員にフリーカンパニーへの帰 属意識の向上を促す機会を提供することで, 仮想世界のサードプレイスとしての機 能を維持・向上させていることが窅える.

\section{6 おわりに一一創発的サードプレイスの成立要件}

本稿では, 従来のサードプレイス論の拡張を目指し, 新たな形態として, 創発的 サードプレイスの形成過程を量的および質的データを用いて明らかにした，以降は， 本稿の内容を整理しつつ, 創発的サードプレイスの成立要件について確認を行う.

本稿で示される仮想世界におけるサードプレイスの創発過程を勘案すると, 創発 的サードプレイスの主要な成立要件は, 次の 2 点に縮約される. 第 1 に, サードプ レイスの基盤を成す「交流」以外の目的として，各成員が能動的に役割を果たさな ければ課題達成が困難な「集団活動」の存在である。具体的には, MMORPGの仮 想世界における「ゲームコンテンツ」や，現実世界においてサードプレイスとして 安定して機能しているとされるスポーツクラブにおける「競技」である。これらの 集団活動経験は, 古籏（1965）の協同の集団効果の観点から, 成員の集団への帰属 意識を芽生えさせ，交流の基盤となる集団を形成・維持している．第 2 に，上述の 「集団活動」と「交流」との間で異なる様相を呈する 2 つ垂直的／水平的な成員 間関係性が，相互に不可侵性を有することである。この性質が，集団内の両活動間 の遷移を円滑化し, 成員の帰属意識を向上させ, 集団を維持・強化する一因となっ 
ている.

仮想世界においては，フリーカンパニー内に，各成員に集団への帰属意識の向上 を促すゲームコンテンツ活動や，その帰属意識を互いに承認し合う機会を提供する 世間話的な交流活動が存在し，それら活動が循環することによって互いの活動基盤 を維持・強化する循環構造が存在する.さらに，フリーカンパニーにおけるゲーム コンテンツ活動と交流活動との循環構造内に存在する関係規範が, 仮想世界におけ るサードプレイスの機能を大きく担う「交流」活動時の成員間の水平的関係性を維 持し，交流を活発化させる一因となっていた，以上のメカニズムが，仮想世界に， プレイヤーにとってゲームを楽しむ場から交流を楽しむ場へと徐々に主役割が移行 する創発的サードプレイスとしての機能を獲得させていた.

今後は，本知見のさらなる一般化可能性を検討するために，国内の仮想世界にお ける種々の同好会に着目したサードプレイスの比較検討を行う必要があろう。

[謝辞］本稿の執筆にあたり, 森田次朗先生（中京大学）と 2 名の查読者の先生方から数多くの 有益なコメントを頂きました。 心よりお礼申し上げます。

\section{[注]}

1）自身が操作するキャラクターを指す.

2）プレイヤーがゲームをプレイする際に繫げる, 接続先のコンピューターを指す.

3）対象者が所属するフリーカンパニーは, 現実世界でのつながりのないプレイヤーらが仮想世 界ではじめて出会い結成した集団である. 本対象集団は, 調査期間内に, 現実世界で実際にプ レイヤー同士が会合する「オフ会」が設けられたことはなかった，筆者は，これまで種々の MMORPG で調查を行い, 10 組以上の同好会に所属してきたが, 現実世界でつながりのあるメ ンバーはほとんど存在せず，オフ会は行われないことが一般的であった，以上の点で，本稿の 対象集団はFFXIV における一般的な同好会であるといえよう.

4）プレイヤー A は女性であり, B から E は男性であった。 また, 全員が 20 歳代後半の会社員 であった. 調查当時, FFXIV プレイヤーの平均年齢は 29.2 歳, かっ, 職業は会社員が最も高 い割合を占めており（メディアクリエイト 2014），その点では, 本調査の対象者はFFXIVの 代表的なプレイヤーといえよう.

5）エンドコンテンツと呼称される当該時点で最も高難度のコンテンツに恒常的に参加するプレ イヤーを指す.

6） 2014 年 8 月 8 日以降は, 以前の推移と同様に長期のコンテンツ欠乏期に入ったため, 紙面の 都合上省略する.

7）アバターの強さの段階を表す数值を指す，敵との戦闘や依頼の完遂によって経験值が得られ， それが一定值に達するとレベルの数值が 1 上昇する. レベルは上限が設定されており, 調查時 点では上限值は 50 であった.

8）以下，対象者の語りに拈りる［］内の補足は筆者によるものである.

9）プレイヤーBの語り.

10）職業は, 剣術士や巴術士など複数種類存在し, 自由に選択できる. 職業によって集団活動時 の役割は大きく異なり, たとえば, 剣術士は敵の攻撃から味方を守り, 巴術士は味方が受けた 傷を癒す役割が期待される. 
11）プレイヤーの相互承認の基に結ばれる仮想世界における友人関係を指す.

12） Damage Per Second の略で1秒あたりに敵に与えるダメージ量を指す. 攻撃役は，この数值 の高さがプレイヤーとしての強さの一指標となる.

13）プレイヤー主導で行われるパーティ内投票の 1 つ. 投票が行われ過半数の賛成が得られると, 制限時間が残っていても自動的に当該コンテンツへの挑戦が終了する.

14） 2002 年に発売された Final Fantasy XI という国内 MMORPG 文化黎明期に流行したタイトル の 1 つ. 仮想世界における活動内容の変遷は, FFXIV と大筋で一致する.

15）効率を第 1 に考えるという常識形成の経緯について，プレイヤーA た時から，2ちゃんねるのネ実 [ネトゲ実況@ 2ch 揭示板］での議論も盛んになった. [中略］ エンドとかレベル上げとか [ゲームコンテンツ］は，基本ガチで［最高効率目指して］やるも のって言う風潮も穾が結構影響してるんじゃないかな：［実際に］ガチでやらない時は，[パ ーティ］メンバー集める時に『まったり』とか伝えとかないと大体揉めた」と述べている.

16）交流場面に扔ける効率化についても，上記掲示板での議論が盛んであったことが複数の対象 者から報告された，その内容としては，会話の妨害，誹謗中傷や，煽りなどの交流場面におけ る代表的な迷惑行為のリストアップや, その迷惑行為を繰り返し行う「迷惑プレイヤー」の象 徵として架空の人物を創造し, 反面教師として扱う事例等が多くみられた。

17）プレイヤーAの語り.

\section{[文献]}

Ducheneaut, N., N. Yee, E. Nickell, and R. J. Moore, 2006, "Building an MMO with Mass Appeal: A Look at Gameplay in World of Warcraft," Games and Culture, 1(4) : 281-317.

久繁哲之介，2007，「都市にサード・プレイスを創る」『Urban Study』46：1-199.

古籏安好, 1965, 「協同と競争に関する実験的研究——集団参加性・集団凝集性および集団生産性

について」『教育心理学研究』13(4) : 193-205.

磯村英一, 1959, 『都市社会学研究』有斐閣.

—，1968，『人間にとって都市とは何か』日本放送出版協会.

川北稔, 2014,「ひきこもり経験者による空間の獲得——支援活動における空間の複数性・対比性 の活用」『社会学評論』65(3): 426-42.

メディアクリエイト，2011，『2011 オンラインゲーム白書』メディアクリエイト． ，2014, 『2014オンラインゲーム白書』メディアクリエイト.

日本オンラインゲーム協会, 2015, 『JOGA オンラインゲーム市場調查レポート2015』エンターブ レイン.

野島美保，2008，『人はなぜ形のないものを買うのか——仮想世界のビジネスモデル』NTT 出版. 荻野達史，2006，「新たな社会問題群と社会運動——不登校，ひきこもり，ニートをめぐる民間活 動」『社会学評論』57(2): 311-29.

Oldenburg, R., 1989, The Great Good Place: Cafés, Coffee Shops, Community Centers, Beauty Parlors, General Stores, Bars, Hangouts, and How They Get You through the Day, New York: Paragon House.

Steinkuehler, C. A. and D. Williams, 2006, "Where Everybody Knows Your (Screen) Name: Online Games as 'Third Places'," Journal of Computer-Mediated Communication, 11(4): 885-909.

高田佳輔, 2016, 「オンラインゲームコミュニティにおける合理的問題解決能力・チームワーク能 
力—Final Fantasy XIV の参与観察を通じて」『社会情報学』5(1)：89-105.

田中康裕・鈴木敦・松原茂樹 - 奥俊信 - 木多道宏, 2007, 「『下新庄さくら園』における目的の形成

に関する考察—コミュニティ・カフェにおける社会的接触」『日本建築学会計画系論文集』 $72(613): 135-42$.

（原稿受付 2017.6.17 掲載決定 2018.8.10) 


\title{
Ethnography of Massively Multiplayer Online Role-playing Games: Cultivating an Emergent Third Place within the Virtual World
}

\author{
TAKADA, Keisuke \\ Chukyo University \\ takadaruman@gmail.com
}

The virtual world that exists in a massively multiplayer online role-playing game (MMORPG) functions as the third place. The third place is a comfortable place away from one's home and workplace. However, the main motive for a player to enter the virtual world of MMORPGs is to enjoy game content, and the circumstances under which and ways in which players participate in the virtual world to interact with others are not clear. In this study, by employing the narratives of players and the transition of game content and exchange activities, the virtual world is revealed to be an emergent third place; the primary role gradually shifts from game content activities to exchange activities through repeating immersion and deficiency periods. The results revealed that reciprocal relations between exchange activities, which form the basis of the third place, and collective activities, which requires players' active participation, are essential to cultivate the emergent third place. Game content activities (vertical membership) improve the cohesiveness and participation of the group by facilitating group achievement of common goals, and as the basis for the communication activities, they maintain and strengthen the connection between members of the community. In addition, relationship norms ensure that vertical relations among members in the game content activities do not negatively affect their horizontal relations in communication activities. Its existence has a significant influence on the creation and maintenance of the emergent third place.

Key words: emergent third place, online community, MMORPG

(Received Jun. 17, 2017 / Accepted Aug. 10, 2018) 